\title{
Kesejahteraan janin pada ibu hamil dengan keluhan nyeri punggung
}

\author{
Sri Wahyuni ${ }^{1^{*}}$, Tutik Rahayu ${ }^{2}$ \\ ${ }^{1,2}$ Fakultas Ilmu Keperawatan, Universitas Islam Sultan Agung Semarang, Indonesia \\ *Coresponding Author: wahyuni@unissula.ac.id
}

\begin{abstract}
Abstrak
Pendahuluan: Adaptasi fisiologis seorang perempuan dalam periode kehamilan seringkali menimbulkan masalah akibat keluhan yang dialaminya. Salah satu permasalahan yang dialami berupa keluhan nyeri punggung yang dialami oleh sebagian besar ibu hamil. Keluhan ini terjadi akibat perubahan fisik selama kehamilan, penambahan ukuran tubuh, penambahan berat badan dan pertumbuhan janin intrauterin yang menyebabkan penambahan masa tubuh ibu. Pembesaran uterus menyebabkan dinding abdomen menjadi teregang, abdomen semakin menonjol sehingga berdampak pada postur tubuh ibu yang berubah menjadi lordosis. Tujuan: dilaksanakannya penelitian ini untuk mengidentifikasi korelasi nyeri punggung terhadap kesejahteraan janin pada ibu hamil di wilayah Kelurahan Bandarharjo Semarang Utara. Metode: Jenis penelitian berupa penelitian kuantitatif yang menggunakan desain cross sectional dengan mengambil subjek penelitian sejumlah 34 orang yang diambil melalui purposive sampling. Hasil: analisa data menggunakan Somers'D dengan hasil $r=0,03$. Simpulan: Nyeri punggung yang dialami oleh ibu hamil berkorelasi sangat lemah terhadap peningkatan denyut jantung janin.
\end{abstract}

Kata kunci: Kesejahteraan janin; ibu hamil; nyeri punggung

Fetal wellbeing in pregnant with back pain complaints

\begin{abstract}
Introduction: Physiological adaptations of a woman in the period of pregnancy that cause problems with the complaints she experiences. One of the problems with complaints is complaints that are presented by most pregnant women. These complaints occur due to physical changes during pregnancy, increase in body size, weight gain, and intrauterine fetal growth which causes additional maternal body mass. The enlargement of the uterus causes the abdominal wall to became stretched, the stomach protrudes more so that it has an impact on the mother's body which turns into lordosis. The purpose of this study was to determine painless attitudes towards fetal welfare in pregnant women in the Bandarharjo Village, North Semarang. Methods: This type is a quantitative research that uses a cross-sectional design by taking a research subject of 34 people taken through purposive sampling. Results: Data analysis used Somers'D with the result $r=0.03$. Conclusions: Which means that pain supported by pregnant women has a very weak correlation with the increase in fetal heart rate.
\end{abstract}

Keywords: Keywords: Fetal wellbeing; pregnant women; back pain

How to Cite: Wahyuni, S \& Rahayu,T. (2019). Kesejahteraan janin pada ibu hamil dengan keluhan nyeri punggung. NURSCOPE: Jurnal Penelitian dan Pemikiran Ilmiah Keperawatan, 6(1), 22-26

\section{PENDAHULUAN}

Kehamilan merupakan proses fisiologis yang dialami oleh seorang perempuan yang sering menimbulkan keluhan-keluhan akibat perubahan hormonal yang terjadi dalam tubuh, seperti keluhan nyeri punggung yang dirasakan hampir 50\% ibu hamil (Sehmbi, D'Souza, \& Bhatia, 2017). Keluhan nyeri terjadi akibat perubahan fisik seperti perubahan ukuran tubuh, penambahan berat badan dan pertumbuhan janin intra uterin yang menyebabkan penambahan masa tubuh. Pembesaran uterus menyebabkan dinding abdomen teregang menyesuaikan perkembangan janin dan menyebabkan abdomen semakin menonjol sehingga postur tubuh menjadi lordosis (Richens, Smith, \& Wright, 2014). Lordosis menyebabkan bagian bahu tertarik ke belakang sebagai kompensasi mempertahankan keseimbangan tubuh. Kondisi ini berdampak pada peningkatan kelengkungan vertebrae menjadi berlebihan, relaksasi sendi sakroiliaka sehingga memicu nyeri punggung (Kartonis et al, 2011). Keluhan 
Nyeri punggung umumnya mulai dirasakan ketika usia kehamilan trimester dua yang meningkat seiring dengan bertambahnya usia kehamilan ibu. Keluhan nyeri punggung akan berdampak pada kualitas hidup ibu hamil karena keluhan nyeri yang sering dirasakannya (Bishop, Holden, Ogollah, \& Foster, 2016).

Keluhan-keluhan yang dirasakan Ibu hamil akibat dari nyeri punggung berpengaruh terhadap kebutuhan tidur serta gangguan emosi (Gharaibeh et al., 2018). Beberapa penelitian menyebutkan bahwa nyeri punggung mempengaruhi adanya gangguan neurologis, gangguan tidur dan gangguan eliminasi BAB maupun BAK (Sehmbi et al., 2017). Nyeri punggung yang dialami oleh ibu hamil berpengaruh terhadap beberapa kondisi fisiologis karena respon nyeri bersifat autonomik. Sementara dalam kondisi hamil di dalam uterus ibu terdapat janin yang sirkulasinya berkorelasi erat dengan sirkulasi darah ibu. Pembuluh darah ibu dan janin bersirkulasi mengalirkan darah melalui sirkulasi uteroplasental (Degner, Magness, \& Shah, 2017). Dengan demikian penting untuk diketahui dampak nyeri punggung yang dialami oleh ibu hamil terhadap kesejahteraan janin selama periode kehamilan.

\section{METODE}

Penelitian dilakukan di wilayah kelurahan Bandarharjo Semarang utara. Jenis Penelitian ini berupa kuantitatif research yang menggunakan desain cross sectional dengan Subjek penelitian ibu hamil yang mengalami nyeri punggung. Sampel sejumlah 34 orang yang diambil dengan cara purposive sampling. Penelitian bertujuan untuk mengidentifikasi korelasi nyeri punggung terhadap perubahan kesejahteraan janin dengan indicator denyut jantung janin. Pengolahan data dilakukan dengan menggunakan Somers' D.

\section{HASIL DAN PEMBAHASAN}

Hasil penelitian yang dilakukan pada 34 orang ibu hamil dengan keluhan nyeri punggung di Kelurahan Bandarharjo Semarang Utara sebagai berikut.

Tabel 1. Identifikasi nyeri punggung pada ibu hamil di Kelurahan Bandarharjo Semarang Utara Tahun 2019 ( $n=34)$

\begin{tabular}{lll}
\hline Nyeri Punggung & Jumlah & Prosentase \\
\hline Nyeri Ringan & 0 & $00.0 \%$ \\
Nyeri Sedang & 19 & $55.9 \%$ \\
Nyeri Berat & 15 & $44.1 \%$ \\
\hline Total & $\mathbf{3 4}$ & $\mathbf{1 0 0 . 0} \%$ \\
\hline
\end{tabular}

Tabel 1 memberikan gambaran bahwa sebagian besar subjek penelitian mengalami nyeri punggung pada derajat sedang yaitu sebanyak dengan sejumlah $55.9 \%$ atau 19 orang, selebihnya subjek penelitian berada pada rentang nyeri punggung sedang.

Tabel 2. Identifikasi kesejahteraan janin berdasarkan jenyut jantung janin pada ibu hamil di Kelurahan Bandarharjo Semarang Utara Tahun 2019 (n=34)

\begin{tabular}{lll}
\hline Denyut Jantung Janin & Jumlah & Prosentase \\
\hline Normal Bawah & 6 & $17.6 \%$ \\
Normal Atas & 28 & $82.4 \%$ \\
\hline Total & $\mathbf{3 4}$ & $\mathbf{1 0 0 . 0} \%$ \\
\hline
\end{tabular}

Tabel 2 menunjukkan bahwa seluruh subjek penelitian mempunyai denyut jantung janin normal, namun sebagian besar denyut jantung janin berada pada kualifikasi normal atas yaitu pada rentang lebih dari 140 - 160 kali tiap menit. Hanya sejunlah 6 subjek penelitian yang mempunyai denyut jantung janin pada rentang normal bawah antara 120-139 kali per menit. 
Tabel 3. Pengaruh nyeri terhadap denyut jantung janin pada ibu hamil di Kelurahan Bandarharjo Semarang Utara Tahun 2019 ( $n=34)$

\begin{tabular}{lllll}
\hline \multirow{2}{*}{ Variabel } & \multicolumn{2}{l}{ Denyut Jantung Janin } & Total \\
\cline { 3 - 5 } & & Normal Bawah & Normal Atas & \\
\hline Nyeri & Sedang & $\mathbf{6}$ & $\mathbf{1 3}$ & $\mathbf{1 9}$ \\
\hline & Berat & 0 & 15 & 15 \\
\hline Total & & $\mathbf{6}$ & $\mathbf{2 8}$ & $\mathbf{3 4}$ \\
\hline$r$ & & & & $\mathbf{0 . 0 3}$ \\
\hline
\end{tabular}

Tabel 3. diperoleh data bahwa seluruh subyek penelitian dengan nyeri punggung berat mempunyai denyut jantung janin dalam rentang normal atas. Hasil ini menunjukkan bahwa peningkatan nyeri berkorelasi dengan meningkatnya denyut jantung janin dengan Somers'd test diperoleh $r$ hitung 0,03 yang menunjukkan menunjukkan nilai korelasi sangat lemah.

Nyeri punggung pada ibu hamil merupakan kondisi yang banyak dialami oleh perempuan hamil dan menimbulkan masalah pada ibu selama kehamilannya (Manyozo, Nesto, Bonongwe, \& Muula, 2019). Nyeri punggung yang sering dikeluhkan oleh hamper sebagian besar ibu hamil terjadi akibat adanya perubahan fisik selama kehamilan seperti perubahan ukuran tubuh, penambahan berat badan dan pertumbuhan janin intra uterin yang menyebabkan penambahan masa tubuh ibu. Pembesaran uterus menyebabkan dinding abdomen menjadi teregang menyesuaikan dengan perkembangan janin di dalam rahim. Peregangan tersebut menyebabkan abdomen semakin menonjol sehingga berdampak pada postur tubuh ibu yang berubah menjadi lordosis (Richens, Smith, \& Wright, 2014).

Penelitian mendapatkan gambaran bahwa terdapat pengaruh antara nyeri punggung pada Ibu hamil dengan kesejahteraan janin yang dalam hal ini indikatornya menggunakan perubahan denyut jantung janin. Nyeri berkaitan dengan system autonomic atau fungsi sistem saraf otonom (Autonomic Nervus System) yang mempengaruhi sistem saraf simpatis pada pasien dan berpengaruh pada perubahan variabilitas detak jantung dan efek perifer dari reaktivitas vaskular (Crofford, 2015). Nyeri punggung yang dirasakan ibu pada saat hamil smerupakan stres tersendiri untuk mempertahankan homeostasis. Pada kondisi stres sistem saraf simpatis menjadi hiperaktif dan menyebabkan perubahan variabilitas denyut jantung sebagai respon psikologis dari stress yang dirasakan (Kim, Cheon, Bai, Lee, \& Koo, 2018). Menurut Tsao dalam penelitiannya yang menyebutkan bahwa nyeri yang dirasakan lama dan berulang meningkatkan berdampak pada respon syaraf parasimpatis dan variabilitas detak jantung (Tsao et al., 2013) .

Sistem pembuluh darah janin berhubungan dengan sirkulasi darah ibu, melalui sirkulasi utero plasental. Selama dalam rahim janin mendapat okslgen dan pertukaran gas melalui peredaran darah plasenta yang terhubung antara ibu dan janin (Kardiovaskuler et al., 2016). Denyut jantung ibu pada saat hamil meningkat 10-20 kali permenit kondisi ini berpengaruh terhadap kondisi janin yang di kandungnya (Sanghavi \& Rutherford, 2014). Pada saat terjadi nyeri pembuluh darah mengalami vasokonstriksi, sehingga berdampak pada sirkulasi utero plasenta dalam mensuplai oksigen dari ibu ke janin. Pada kondisi ini, denyut jantung janin akan meningkat sebagai kompensasi untuk memenuhi kebutuhan oksigen (Tamás et al., 2007).

Penilaian terhadap denyut jantung janin merupakan salah satu indikator untuk menentukan kesejahteraan janin. Penilaian terhadap kesejahteraan janin merupakan cara yang dapat dilakukan oleh tenaga kesehatan untuk mengetahui kondisi janin dalam uterus. Melalui pemantauan akan dapat diketahui kondisi janin dan plasenta apakah mengalami insufisiensi atau tidak. Pemantauan pralahir mampu untuk mendeteksi kondisi kesejhteraan janin sehingga akan dapat menekan angka kematian 
bayi baru lahir, menurunkan janin lahir dengan resiko tinggi, menurunkan angka persalinan premature dan menurunkan angka kesakitan (O'Neill \& Thorp, 2012).

Pemantauan denyut jantung janin dapat digunakan sebagai salah satu indicator kesejahteraan janin, pemantauan denyut jantung janin mampu mendeteksi janin dalam kondisi mengalami asidosis atau tidak. Denyut jantung yang lambat berdampak pada PH darah arteri umbilical pada janin (Makino, Hirai, Takeda, Itakura, \& Takeda, 2017).

\section{SIMPULAN DAN SARAN}

Seluruh subjek penelitian memiliki denyut jantung janin normal, namun terdapat peningkatan denyut jantung janin pada ibu hamil yang mengalami nyeri lebih berat. Sehingga dapat disimpulkan nyeri punggung yang dialami oleh ibu hamil berkorelasi sangat lemah terhadap peningkatan denyut jantung janin. Diharapkan setiap ibu hamil melakukan kunjungan antenatal care sesuai dengan jadwal yang sudah ditentukan agar kesejahteraan ibu dan janin meningkat.

\section{DAFTAR PUSTAKA}

Bishop, A., Holden, M. A., Ogollah, R. O., \& Foster, N. E. (2016). Current management of pregnancyrelated low back pain: A national cross-sectional survey of UK physiotherapists. Physiotherapy (United Kingdom), 102(1), 78-85. https://doi.org/10.1016/j.physio.2015.02.003

Crofford, L. J. (2015). Chronic Pain: Where the Body Meets the Brain. Transactions of the American Clinical and Climatological Association, 126, 167-183.

Degner, K., Magness, R. R., \& Shah, D. M. (2017). Establishment of the Human Uteroplacental Circulation: A Historical Perspective. Reproductive Sciences, 24(5), 753-761. https://doi.org/10.1177/1933719116669056

Gharaibeh, A., A, A. W., Qdhah, E., Khadrawi, M., A, A. S., \& Qaoud, Y. (2018). Prevalence of Low Back Pain in Pregnant Women and the Associated Risk Factors Journal of Orthopedics \& Bone Disorders, 1-7.

Kardiovaskuler, S., Bayi, P., Lahir, B., Agus, K., Putra, H., An, S., ... Isi, D. (2016). dr. Kadek Agus Heryana Putra, Sp.An dr. Pontisomaya Parami, Sp.An, MARS.

Kim, H. G., Cheon, E. J., Bai, D. S., Lee, Y. H., \& Koo, B. H. (2018). Stress and heart rate variability: A meta-analysis and review of the literature. Psychiatry Investigation, 15(3), 235-245. https://doi.org/10.30773/pi.2017.08.17

Makino, S., Hirai, C., Takeda, J., Itakura, A., \& Takeda, S. (2017). Relationship between fetal heart rate patterns and a time course for evaluation of fetal well-being: "the 30 minutes rule" for decision of mechanical delivery. Taiwanese Journal of Obstetrics and Gynecology, 56(6), 788-792. https://doi.org/10.1016/j.tjog.2017.10.015

Manyozo, S. D., Nesto, T., Bonongwe, P., \& Muula, A. S. (2019). Low back pain during pregnancy: Prevalence, risk factors and association with daily activities among pregnant women in urban Blantyre, Malawi. Malawi Medical Journal, 31(1), 71-76. https://doi.org/10.4314/mmj.v31i1.12

O'Neill, E., \& Thorp, J. (2012). Antepartum evaluation of the fetus and fetal well being. Clinical Obstetrics and Gynecology, 55(3), 722-730. https://doi.org/10.1097/GRF.0b013e318253b318

Richens, Y., Smith, K., \& Wright, S. L. (2014). Lower back pain during pregnancy: advice and exercises 
for women. British Journal of Midwifery, 18(9), 562-566. https://doi.org/10.12968/bjom.2010.18.9.78064

Sanghavi, M., \& Rutherford, J. D. (2014). Cardiovascular physiology of pregnancy. Circulation, 130(12), 1003-1008. https://doi.org/10.1161/CIRCULATIONAHA.114.009029

Sehmbi, H., D'Souza, R., \& Bhatia, A. (2017). Low Back Pain in Pregnancy: Investigations, Management, and Role of Neuraxial Analgesia and Anaesthesia: A Systematic Review. Gynecologic and Obstetric Investigation, 82(5), 417-436. https://doi.org/10.1159/000471764

Tamás, P., Szilágyi, A., Jeges, S., Vizer, M., Csermely, T., Ifi, Z., ... Szabó, I. (2007). Effects of maternal central hemodynamics on fetal heart rate patterns. Acta Obstetricia et Gynecologica Scandinavica, 86(6), 711-714. https://doi.org/10.1080/00016340701252217

Tsao, J., Evans, S., Seidman, L., Lung, Zeltzer, L., \& Naliboff, B. (2013). Heart rate variability as a biomarker for autonomic nervous system response differences between children with chronic pain and healthy control children. Journal of Pain Research, 449. https://doi.org/10.2147/jpr.s43849 